\title{
Communication of silence at Ludwig Wittgenstein: Linguistic Silence
}

\author{
Ștefan Vlăduțescu \\ Department of Romance Language and Communication, Faculty of Litters, University of Craiova, \\ A. I. Cuza, no. 13, Craiova, Romania \\ E-mail address: stefan.vladutescu@yahoo.com
}

\begin{abstract}
The study explores the specifics of silence at Ludwig Wittgenstein. The starting premise is that silence is a manifestation of intentional communication. If silence is intentional, however, quiet is always unintentional. Ludwig Wittgenstein discovers that reflective thinking can be expressed either by language, either by silence. He develops the thesis of linguistic silence: "Whereof one cannot speak, thereof one must be silent." Linguistic silence communication dimensions are explained.
\end{abstract}

Keywords: communication; silence; quiet; linguistic silence

\section{INTRODUCTION}

Ludwig Wittgenstein discovers philosophy as a gracious, benevolent accusation against language. He has nothing against language itself, but against its limits. Actually, he is not unkind to those either. The observation of the language limits is an act of submission.

The seventh thesis of the Tractatus is the thesis of linguistic silence. "Whereof one cannot speak, thereof one must be silent" (7) (Wittgenstein, 1961). Knowledge is larger than language. Let us remember that for Dionysius the Areopagite the word is larger than knowledge; cognition is seen as being separate from language. There is a cognition which can be linguistically formated and philosophically expressed. But there is also another cognition which cannot be verbalized, which must be yielded to silence. Basically, Wittgenstein claims that thought is unlimited, whereas language is limited: where language does not cover thought anymore linguistic silence takes over. Hence, in order to fully express itself, thought uses both language and silence. It can be inferred that it is a silence of the language, a linguistic silence. S. Zizek considers that "The primordial fact is not Silence (waiting to be broken by the divine word) but the noise, the confuse murmur of the Real in which there is not yet distinction between a figure and its background. The first creative act is therefore to create silence" (Zizek, 2006, p. 224) (also Baker, 1955; Zeligs, 1961; Jensen, 1973; Johannesen, 1974; Jaworski, 1997). The reason to support the infinity of thought is given by the impossibility to think beyond thought. In order to trace a limit of thought, says Wittgenstein, one should be able to think both sides of that limit. One should, therefore, "be able to think what cannot be thought". The absurd of actually thinking what cannot be thought cancels the limit: thought has no limits. 


\section{TOWARD A LINGUISTIC SILENCE}

The object of philosophy is a problem of language and of thoughts: "The object of philosophy is the clarification of thoughts. Philosophy is not a theory, but an activity. A philosophical work consists essentially of elucidations (4112) (Wittgenstein, 1961). In this regard, philosophy must ensure a suitable language to thought, transforming itself in an act that consists essentially of elucidations. Any elucidation is an elucidation by language. It becomes necessary, as language is narrow. By no means relinquishing the elucidation of language, philosophy functions appears as "language criticism" and as an activity, not a doctrine: „Philosophy is not a theory but an activity” (4.112) (Wittgenstein, 1961).

For Wittgenstein the world is the sum of the facts that take place. "The facts in the logical space are the world" (1.13) (Wittgenstein, 1961). The facts are the image of thought. These images compose a fundamental representation since they have in common with the facts "the logical form of representation" (2.2.) (Wittgenstein, 1961). The image has no obligation as regards being true or false. It represents what it represents "through its form of representation". Vericonditional independence rules out the a priori truthfulness of the image. Thought has, in Wittgenstein's view, a cogitational aspect and a linguistic aspect. It is first of all a logical image of the facts "The logical picture of the facts is the thought" (3) (Wittgenstein, 1961), and second of all it is a proposition with a significance: "the thought is the significant proposition"(4) (Wittgenstein, 1961).

Wittgenstein's cogitation is strictly logical and verbalizing it must be meaningful. In order to exist, speech must be a representation. The word, the discourse, the logos have the picture as a model. The language of fact edification is conditioned by logic. The language of reason is reduced to a perfectly logic language. What remains outside logical language is silence. Hanna Appleqvist speaks about "facts that are expressible in meaningful language and that which must be passed over in silence" (Appelqvist, 2013, p. 44) (also Neacșu, 2006; Ionescu, 2008).

Seen in the amplitude of human experience manifestations, the language of silence is not uniform. Human experience has illogical parts as well. Because of this deficiency, it does not benefit from a logical expression. Consequently, everyday language represents a component of silence. The substance of silence is illogical, a-logical, pseudo-logical, hypo-logical or brahilogical. If the object of philosophy is of reasoning and logical nature, it then follows that wisdom, which is not absolutely and permanently logical, has one more component (Bruneau \& Satoshi, 1988; Tannen \& Saville-Troike, 1985; Bilmes, 1994). Wittgenstein's philosophy only deals with those thoughts that are supported logically, the rest being discarded into linguistic silence. Beyond logical analysis, a secondary philosophical practice is not admitted. The method of logical philosophy would consist of "say nothing except what can be said" (6.53) (Wittgenstein, 1961). When someone wants to say something metaphysical, the method demands "To demonstrate to him that he had given no meaning to certain signs in his propositions".

Thought is infinite in Wittgenstein's view and it functions in a logical space. The other two elements of Wittgenstein's discourse universe are the world and the language. "The limits of my language mean the limits of my world" (5.6) (Wittgenstein, 1961). The reasoning subject has a world of facts, a world of his own. The only thing that he understands is this language "the language which only I understand" (5.62) (Wittgenstein, 1961). It seems uncharacteristic of Wittgenstein to notice that what can be comprehended is not the world, but the language. As such, the comprehension of the world is bound to be circumscribed to the limits of the language. A limited language is the indicator of a limited world (Dumitru, 2004; Ghenea, 2006). 
At the level of cogitation, "logic fills the world: the limits of the world are also its limits" (5.61) (Wittgenstein, 1961).

As the world and the language are measurable, it follows that to state that "logic fills the language" says something about the philosophical exigency of the language logical construction. In order to be able to represent the world, the language needs to have a logical structure. Silence remains the illogical part of language. Silence does not limit only the language, but the world as well, since the limits of the language are the limits of the world. Language can have a wider or more narrow range, logic, however, is fixed. As such, silence must be adopted when the logic is silent (Le Breton, 1997; Țenescu, 2009; Gîfu \& Cristea, 2011; Ionescu, 2013).

Logic censures everything, but it becomes deficient when applied to silence. Illogical language is left in the form of silence called discretion. The Wittgenstein of the Tractatus conceives silence as being philosophical only as far as speech can be logical: "Whereof one cannot speak <logically> (our addition, author Ștefan Vlăduțescu), thereof one must be silent"(7). Discourse must be logical. Unable to be logical, it must be silent. It is not an option, it is the end of a range: rather than miss the logic of expression, one should be silent. Thus, linguistic silence defines itself as a punishment for being illogical. To admit silence means to agree that language is not totally logical. After all, it is commonly acknowledged that the "logical space" defines a silence. Through the perfection of language itself, a space of silence is separated (Kulczycki, 2012; Vlăduțescu, 2013a; Vlăduțescu, 2013c).

Silence signifies in the same manner as the facts in the logical space, but it brings meaning as a boldness, a significance and an abdication from logic. Consequently, the semantic, semiotic and logical plans are exceeded. Silence is tied from the outside to the logic, it establishes itself on the linguistic edge of formal exigency. It has nothing to do with what is unutterable or secret.

With regard to his contribution in the improvement of the linguistic apparatus of philosophy, Wittgenstein is totally defeated, because his logical language has a limit, called silence. He is defeated, as he does not belong to the world: "the subject does not belong to the world but it is the limit of the world" (5.632) (Wittgenstein, 1961).

In order not to yield everything, Wittgenstein interposes between speech and silence what can be shown: "but that can clearly not be said: it shows itself" (6.36) (Wittgenstein, 1961). P. R. Horn specifies "As Wittgenstein said in a letter to Bertrand Russell, the distinction between what can and what cannot be expressed by the propositions of language is the central aim of the Tractatus. This is the distinction between saying and showing" (Horn, 2005, p. 103).A language of the sight takes from the linguistic silence. To show is not a part of silence, but it is not an act of saying, either. Sight cannot be silent but it is not logical either. It is not within the "logical space" but it does not propel silence either. A part of what cannot be said can be shown. When it becomes sight and silence, says Wittgenstein, "logic must take care of itself" (5.473) (Wittgenstein, 1961).

Logic takes care of the language of silence and the language of showing. Moreover, it deals with itself. On the other hand, it deals with itself precisely as a superlative of musing over everything. Logic pays attention to everything, but only within the logical space can it fully express itself as logic. Beyond the logical space, logic falls silent or it shows, purely by means of language (Vlăduțescu, 2004; Ogonowska, 2005; Vlăduțescu, 2009). Silence barely has a logical cover, its essence is linguistic. Discourse signifies only by means of the logical part of expression, by means of its silence-showing part, it merely indicates. The Tractatus itself, like any expression, says Wittgenstein, has two parts: "one which is shown and one that I haven't written yet, the latter being the true one". 
Our thesis is that language comes after. As such, we can find support in Wittgenstein: what is important comes after, the not-written perfects the work. The true words are uttered in absence, as a celebration of the absence. The message reaches us after the discourse perishes. The logos is buried in the message. Universal logical speech becomes visible as a sequential message. The logical space becomes message when it is absorbed as silence: on these grounds S. Bindemann bases his thesis according to which for Wittgenstein and Heidegger "silence itself represents a way for speech to function beyond the power of words" (Bindemann, 1981, p. 7). The methodological demands and enforcing the logical analysis from the Tractatus will turn out to be impossible to implement in the Wittgenstein II period (Vlăduțescu, 2013b). "Philosophical Investigations" move the examination from the logical space towards the former logical space of silence and showing. Former logical language is represented by common language. Here logical analysis of the language overcomes itself. It is labeled as "gradual liberation from interpretation".

There is no new conception about the language in "Philosophical Investigations", but an extension of the analysis of daily language, a part of the silence in Tractatus. Silence defines itself as a place of language games in which the meaning of the word is given by its usage in the discourse. Logic and philosophy find solace in giving up being logical in order to come closer to the factual use of language. Philosophy used to be an activity, now speaking a language becomes part of an activity or part of a form of life. In the activity called language game, the words no longer refer to a certain logic, but only to the momentum of usage. Language games bring pragmatics in the field of philosophy. Speech has an action function which manifests itself in the language games. Now philosophy "looks on the language-game as the primary thing" (656) (Wittgenstein, 2009). From logic, we move on to grammar. Whereas the limit used to be drawn by logic, in the field of silence the delimitations are made by grammar. "Essence is expressed by grammar" (371) (Wittgenstein, 2009). After all, grammar is the logic of everyday language. It is grammar that excludes the possibility of a private language. The limits of speech have been overcome towards silence, and the limits of silence are enveloped as language games. C. Kenny shows that "Silence manifests in many forms" (Kenny, 2011, p. 69); the form that illustrates Wittgenstein is linguistic silence.

\section{CONCLUSION}

Ludwig Wittgenstein shows about "Tractatus Logico-Philodophicus": "The whole sense of the book might be summed up in the following words: what can be said at all can be said clearly, and what we cannot talk about we must consign to silence" (Wittgenstein, 1961, p. 3). Silence guides both as ex-logical linguistic presence and as linguistic limit of the logic. With Wittgenstein we are not merely dealing with a phenomenon of silence, but with an accomplishment, with a conceptual figuration of the limits of language, with a communication of silence, with linguistic silence.

"What cannot be spoken" constitutes a determined linguistic presence. Through silence the absolute limits of language are reached.

Dr. Ștefan Vlăduțescu is a graduated of the Faculty of Philology (University of Craiova), as valedictorian country, with special "Diploma of merit". Also, is a graduated of Faculty of Law, University of Bucharest. Obtained his doctorate in Philosophy from University of Bucarest (with the thesis "Communication and Message in Philosophy"). Is Associate Professor at University of Craiova. Is a member of International Association of Communication (ICA), a member of Romanian Writer's Union, and a member of Romanian Association of Press History. Is editor in chief of Annals of University of Craiova. Section Communication. Media, and a member of editorial board of Annals of University of Craiova. Section Linguistics. He is author or co-author of 14 professional 
books, of 110 scientific papers in Romania and international journals (including ISI/Thompson Reuters articles), and in proceedings of international seminars and conferences.

\section{References}

[1] Appelqvist H. (2013). Why does Wittgenstein say that ethics and aestehics are one and the same. In P. Sullivan \& M. Potter (Eds.), Wittgentein's Tractatus: History and Interpretation (pp. 40-58). Oxford: Oxford University Press.

[2] Baker S., Journal of General Psychology 53 (1955) 145-167.

[3] Bilmes J., Semiotica 98 (1994) 73-87.

[4] Bindemann S.-J. (1981). Heidegger and Wittgenstein: The Poetics of Silence. Washington: University Press of America.

[5] Bruneau T., Satoshi I., World Communication 17(1) (1988) 1-33.

[6] Dumitru,M. (2004). Explorări logico-filosofice. Humanitas.

[7] Ghenea V. (2006). Language and reality. Some aspects of realism in the philosophy of language. Analele Universitatii din Craiova, Seria Filozofie, (17),157-165.

[8] Gîfu D., Cristea, D. (2011). Computational techniques in political language processing: AnaDip - 2011. In Future Information Technology (pp. 188-195). Springer Berlin Heidelberg.

[9] Ionescu A. (2008). Modalisateurs illocutoires et argumentation. Craiova: Editura Universitaria.

[10] Ionescu D., Journalism and Mass Communication 3(8) (2013) 528-531.

[11] Horn P. R. (2005). Gadamer and Wittgenstein on the Unity of Language: Reality and Discourse without Metaphysics. Hampshire: Ashgate Publishing.

[12] Jaworski A. (Ed.) (1997), Silence: Interdisciplinary Perspectives. Berlin, New York: Mouton De Gruyter.

[13] Jensen J. V., ETC 30 (1973) 249-257.

[14] Johannesen R. L., Western Speech 38(1) (1974) 25-35.

[15] Kenny C. (2011). The Power of Silence. Silent Communication in Daily Life. London: Karnac Books.

[16] Kulczycki E. (2012). Komunikologia. Teoria i praktyka Komunikacji. Poznan: IF UAM.

[17] Le Breton D. (1997). Du silence: essai. Editions Métailié.

[18] Neacşu A. (2006). Arheologia şi evoluţia conceptelor filosofice. Editura Universitaria.

[19] Ogonowska A., Nowa Polszczyzna 4(44) (2005) 33-37.

[20] Saville-Trike S. (1985). The place of silence in an integrated theory of communication. In D. Tannen, D., \& M. Saville-Troike (1985). Perspectives in silences. In D. Tannen \& M. Saville-Troike (Eds.), Perspectives in silences (pp. 3-18). Norwood, NJ: Ablex.

[21] T,enescu A. (2009). Comunicare, sens, discurs. Craiova: Editura Universitaria. 
[22] Vlăduțescu Ştefan (2004). Mesagologie și Comunicologie. Craiova: Editura Sitech.

[23] Vlăduțescu Ştefan (2009). Concepte şi noţiuni de Comunicare şi Teoria mesajului. Craiova: Editura Sitech.

[24] Vlăduțescu Ștefan (2013a). Jokull Journal 63(8) (2013) 186-197.

[25] Vlăduțescu Ștefan (2013b). Jokull Journal 63(9) (2013) 301-318.

[26] Vlăduțescu Ştefan (2013c). International Journal of Management Sciences and Business Research 2(8) (2013) 1-9.

[27] Wittgenstein L. (1961). Tractatus Logico-Philosophicus. London: Routledge \& Kegan Paul.

[28] Wittgenstein L. (2009). Philosophical Investigations. (4th ed.) Oxford: Wiley-Blackwell.

[29] Zeligs M. A., Journal of the American Psychoanalitic Association 9(1) (1961) 7-43.

[30] Zizek, S. (2006). Burned by the sun. In S. Zizek (Ed.), Lacan: The Silent Partners (pp. 217-230). New York: Verso. 